\title{
The Changes of Phosphorus and Potassium in Soil Under Different Lime Rates
}

\author{
Janis Vigovskis, Agrita Svarta, Aivars Jermuss, Daina Sarkanbarde \\ Institute of Agronomy of Latvia University of Agriculture \\ Address: Zemkopības institūts 7, Skrīveri, LV-5125, Latvia
}

\begin{abstract}
The paper describes the influence of liming to phosphorus and potassium accumulation in soil. The research has been carried out at the Institute of Agronomy of Latvia University of Agriculture in the long-term subsurface drainage field established in Skriveri in 1981. The experimental field was established with four rates of mineral fertilizers: without fertilizers (FO), N45P30K45 (F1); N90P60K90 (F2), N135P90K135 (F3) and four rates of lime: without liming

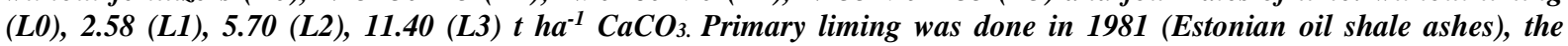
maintenance liming was performed in 1994 (dolomitic limestone) and 2014 (BALTKALK).

After 35 years of trial similar soil parameters showed significantly different content of phosphorus and potassium related to the different rates of liming in all fertilizing levels. Without fertilizers, the liming provided the increase of phosphorus content in soil from 14 to $36 \mathrm{mg} \mathrm{kg}^{-1}$, but the increase of potassium - from 55 to $72 \mathrm{mg} \mathrm{kg}^{-1}$. On a low background of fertilizers (N45P30K45) the content of phosphorus and potassium under liming increased respectively from 20 to $32 \mathrm{mg} \mathrm{kg-1}$ for phosphorus and 75 to $96 \mathrm{mg} \mathrm{kg}^{-1}$ for potassium. At the fertilizers level N90P60K90 the content of phosphorus and potassium increased respectively from 94 to $81 \mathrm{mg} \mathrm{kg}^{-1}$ for phosphorus and 115 to $165 \mathrm{mg} \mathrm{kg}^{-1}$ for potassium. At the fertilizers level N135P90K135 the content of phosphorus and potassium increased respectively from 174 to $203 \mathrm{mg} \mathrm{kg}^{-1}$ for phosphorus and 166 to $214 \mathrm{mg} \mathrm{kg}^{-1}$ for potassium.
\end{abstract}

Keywords: Liming, phosphorus, potassium, soil pH, long-term field experiment.

\section{INTRODUCTION}

Phosphorus and potassium are important macronutrients in plant life cycle. Phosphorus is aplant energy store and source in theform of adenosine diphosphate (ADP) and adenosine triphosphate(ATP) and can be found in proteins, enzymes and phospholipids. Potassium is associated with movement of water in plantand involved with enzyme activation within the plant which affects protein, starch and ATP production. However, plant available forms of thosemacronutrients in soil are limited and affected by many agrochemical factors.

Soil acidity is a parameter affecting the solubility and suitability of nutrients in soil. Factors affecting soil $\mathrm{pH}$ include organic matter decomposition, transformation into compounds available for plant nutrition. Nutrient intake changes depending on the soil $\mathrm{pH}$ [1].The concentrations of phosphorus had ' $U$ shaped' relations with $\mathrm{pH}$, with minima in the intermediate $\mathrm{pH}$ range $(\mathrm{pH}$ 6.0-7.0). Decreasing solubility with increasing $\mathrm{pH}$ from 5 to 7 , most distinct for the oxoionic element $\mathrm{P}$, would be caused by the formation of less soluble Ca phosphate and, respectively, with increasing $\mathrm{Ca}$ concentration and $\mathrm{pH}$. The distinct increase in the concentrations of most of these elements above $\mathrm{pH} 7$ is related to the simultaneous increase in the concentration of soluble organic C [2]. The results of other researches show that after soil liming, the plant available phosphorus content in soil increased. Regular application of lime in 10 years resulted in an increase of $\mathrm{pH}$ value as well as organic carbon, plant available phosphoruscontent [3]. The application of lime ( 3 and $12 \mathrm{t} \mathrm{CaO} \mathrm{ha}^{-1}$ ) increased the $\mathrm{pH}$ in average from 6.6 up to 7.0 and 7.2 , but did not decrease extractable $\mathrm{P}$ below the level of untreated control [4] - [6]. An increase in the available phosphorus content in strongly acidic soil after liming was also recorded in other experiments [7] - [10]. Great effect on yield of winter triticale and $\mathrm{N}$ and $\mathrm{P}_{2} \mathrm{O}_{5}$ usage coefficients was done by combined application of NPK, lime and manure fertilizers [11], [6].The researches in Croatia show that soil $\mathrm{pH}$ increment by liming significantly increased phosphorus availability from 1.8 till $4.9 \mathrm{mg} \mathrm{kg}^{-1}$ per t $\mathrm{ha}^{-1} \mathrm{CaCO} 3$ [8]. Regarding s12il available phosphorus considerably higher effects of carbocalk compared to dolomite treatment were found. Four years after carbocalk application, phosphorus content was increased for $12 \mathrm{mg} 100 \mathrm{~g} \mathrm{~g}^{-1}$ at the highest rate, while significant increase of soil available

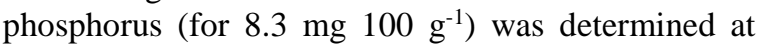
treatment with $18 \mathrm{t} \mathrm{ha}^{-1}$ dolomite [9]. Applying $\mathrm{P}$ fertilizer without soil testing may lead to $\mathrm{P}$ build up in soils, hence, increased $\mathrm{P}$ runoff potential [13]. Accumulation ofthe total $\mathrm{P}$ in the arable layer of soil had a tendency to decrease with increasing soil $\mathrm{pH}$. The lowest amount ofthe total $\mathrm{P}$ was determined in soil with $\mathrm{pH}_{\mathrm{KCl}} 6.7$ [14]. http://dx.doi.org/10.17770/etr2017vol1.2571 
Liming without $\mathrm{P}$ fertilization increased plant $\mathrm{P}$ satisfactorily only in the high-P soil. $\mathrm{P}$ fertilising alone is a better practice than liming alone for improved plant growth conditions in acidic, low-P soils, unless there is relatively high $\mathrm{P}$ content in soil, in which case liming alone may be sufficient to increase $P$ availability [10].

The application of lime believed to enhance soil health status through improving soil $\mathrm{pH}$, base saturation, $\mathrm{Ca}$ and $\mathrm{Mg}$. It reduces $\mathrm{Al}$ and $\mathrm{Mn}$ toxicity and increases both $\mathrm{P}$ uptake in high $\mathrm{P}$ fixing soil and plant rooting system [15].

Concentrations of potassium in soil solution decreased with rising $\mathrm{pH}$ [2]. The results of researches show that after 10 years soil liming, the plant available potassium content in soil decreased [3]. A laboratory experiment in India showed that nitrogen and potassium fertilizers treatments and liming initially decreased the water soluble and exchangeable $\mathrm{K}$ but increased the non-exchangeable $\mathrm{K}$ in soil. Water soluble $\mathrm{K}$ was significantly increased in limed soil throughout its incubation period, whereas it showed a decreasing trend in unlimed acid soil. Highest amount of exchangeable $\mathrm{K}$ was observed in acid soil after 90 days of incubation, whereas water soluble and non-exchangeable $\mathrm{K}$ were found to be highest in half and full limed soil respectively. Combined application of nitrogen and potassium fertilizer significantly increased the water soluble K [16].

Results of Austrian scientists estimatedthe increase of $\mathrm{pH}$ level in average from 6.6 up to 7.0 and 7.2 by application of lime ( 3 and $\left.12 \mathrm{t} \mathrm{CaO} \mathrm{ha}^{-1}\right)$ and there was no the decrease of extractable $\mathrm{K}$ below the level of untreated control observed. The extractable $\mathrm{K}$ in $\mathrm{CaO}$ treated soil remained still above the untreated control [5].

The researches in Croatia show that soil $\mathrm{pH}$ increment by liming significantly increased potassium availability from 1.3 till $1.5 \mathrm{mg} \mathrm{kg}^{-1}$ per t $\mathrm{ha}^{-1} \mathrm{CaCO}_{3}$ in soil and their transfer into aboveground plant organs [12]. Liming with carbocalk significantly decreased potassium availability at $45 \mathrm{t}$ $\mathrm{ha}^{-1}$ and higher rates, whilst dolomite did not affected soil potassium content [9].

\section{MATERIALS AND METHODS}

\section{Site and soil description.}

The research was carried out at the Research Institute of Agronomy of Latvian University of Agriculture in the long-term subsurface drainage field experiment "Sidrabini,". Field experiment established in Skriveri in 1981 under the guidance of professor Juris Štikāns. The paper presents the experimental data from the 1981-2014 periods. The long-term drainage field experiment was established on the uncultivated gleyic sod-podzolicHypostagnic EndogleyicAlbeluvisol (Hypereutric, stw-ng-AB(he)) loam that had not been used in agriculture for 20 years before.

Experimental design.

The four rates of mineral fertilizers: $\mathrm{F} 0$ - without fertilizers, F1 - $\mathrm{N}_{45} \mathrm{P}_{30} \mathrm{~K}_{45}, \mathrm{~F} 2-\mathrm{N}_{90} \mathrm{P}_{60} \mathrm{~K}_{90}$ and $\mathrm{F} 3-$ $\mathrm{N}_{135} \mathrm{P}_{90} \mathrm{~K}_{135}$ calculated in form of $\mathrm{P}_{2} \mathrm{O}_{5}$ and $\mathrm{K}_{2} \mathrm{O}$ were used together with four rates of liming: $\mathrm{LO}$ - without liming, $\mathrm{L} 1-2.58 \mathrm{t} \mathrm{ha}^{-1} \mathrm{CaCO}_{3}, \mathrm{~L} 2-5.70$ and $\mathrm{L} 3-$ $11.40 \mathrm{t} \mathrm{ha}^{-1} \mathrm{CaCO}_{3}$ (slate ash with $80 \%$ neutralizing value) (Fig. 1). Primary liming was done in 1981 (Estonian oil shale ashes with $415.4 \mathrm{~g} \mathrm{~kg}^{-1} \mathrm{CaO}, 44 \mathrm{~g}$ $\mathrm{kg}^{-1} \mathrm{MgO}, 21 \mathrm{~g} \mathrm{~kg}^{-1} \mathrm{~K}_{2} \mathrm{O}, 2.1 \mathrm{~g} \mathrm{~kg}^{-1} \mathrm{P}_{2} \mathrm{O}_{5}$ and $76 \mathrm{~g} \mathrm{~kg}^{-1}$ $\mathrm{SO}_{3}$ ), the maintenance liming was performed in 1994 (dolomitic limestone with $97.0 \%$ neutralizing ability, $188 \mathrm{~g} \mathrm{~kg}^{-1} \mathrm{Ca}, 120 \mathrm{~g} \mathrm{~kg}^{-1} \mathrm{Mg}$, humidity content $\leq 0.2 \%$, amount of particles smaller than $1 \mathrm{~mm} \mathrm{-}$ 99.5\%) and 2014 (BALTKALK with $97.6 \%$ neutralizing ability, $333 \mathrm{~g} \mathrm{~kg}^{-1} \mathrm{Ca}, 6.9 \mathrm{~g} \mathrm{~kg}^{-1} \mathrm{Mg}$, humidity content $8-16 \%$, amount of particles smaller than $1 \mathrm{~mm}-88.8 \%)$. The total area (1.6 ha) of the experimental field was divided into 16 plots $(15 \times$ $50 \mathrm{~m})$.

Agronomic practices.

Since 1994, a seven-year crop rotation was created: (1) winter triticale $\rightarrow$ (2) potato, $\rightarrow$ (3) spring wheat $\rightarrow$ (4) spring oilseed rape $\rightarrow$ (5) spring barley undersown with perennial grasses $\rightarrow$ (6) perennial grasses, $1^{\text {st }}$ year of use, and $\rightarrow(7)$ perennial grasses, $2^{\text {nd }}$ year of use. In the sowing year, mixtures of herb species were sown under barley. In the first rotations the components of mixtures were Phleumpratense and Trifoliumpratense, but in 2012 a mixture of Trifoliumpratense, Festucapratensis, Phleumpratense and Festulolium was made.

Traditional soil tillage was used including mouldboard ploughing (for winter crops - in the previous autumn, for spring crops - after harvest of previous crops), cultivation and rototilling before sowing. Mineral fertilizers were applied according to the anticipated rates of plant nutrient elements annually during the pre-sowing cultivation of soil. For winter crops the phosphorus as single superphosphate and potassium as potassium chloride were applied before the sowing in autumn and nitrogen in the form of ammonium nitrate was applied the next spring at the beginning of vegetation and at the tillering stage. During the growing season all the required common soil and crop management practices were applied - treatment with herbicides, fungicides and insecticides.

Experimental methods and assessments

The soil for agrochemical analyses was sampled from $0-20 \mathrm{~cm}$ depth annually after harvesting. Soil samples were taken in each plot using a $12 \mathrm{~mm}$ diameter steel auger, and the samples from each plot were mixed, dried and sieved. The content of phosphorus and potassium in soil was extracted from acid calcium lactate. Soil acidity $\left(\mathrm{pH}_{\mathrm{Cl}}\right)$ was 
determined according to the standard LVS ISO 10390:2006 Soil quality - Determination of $\mathrm{pH}$.

Statistical analyses.

The obtained data mathematical processing was performed using analysis of variance (ANOVA).

Meteorological conditions.

The long-term experiment is located in the central part of Latvia (latitude N 56 $38^{\prime}$, longitude E $25^{\circ} 08^{\prime}$ ). The annual precipitation amount is normally $670 \mathrm{~mm}$. The annual air temperature is $+5.7^{\circ} \mathrm{C}$. The winter average air temperature is $-4.3^{\circ} \mathrm{C}$. The duration of the growing season is 180-210 days.

\section{RESULTS AND DISCUSSION}

At the beginning of the experiment the soil was very strongly acid $\left(\mathrm{pH}_{\mathrm{KCl}} 4.7-4.9\right)$ with very low content of available phosphorus (10-20 mg $\left.\mathrm{P}_{2} \mathrm{O}_{5} \mathrm{~kg}^{-1}\right)$ and low content of available potassium (40-60 mg

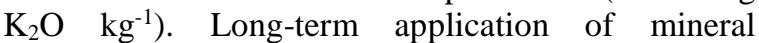
fertilizers to agricultural soils leads to accumulation of plant nutrients (phosphorus and potassium) in soil and depended on fertilizer rates [17] - [18].

The results show that the liming provided the increase of available phosphorus in soil (Fig.1 and Fig. 2).

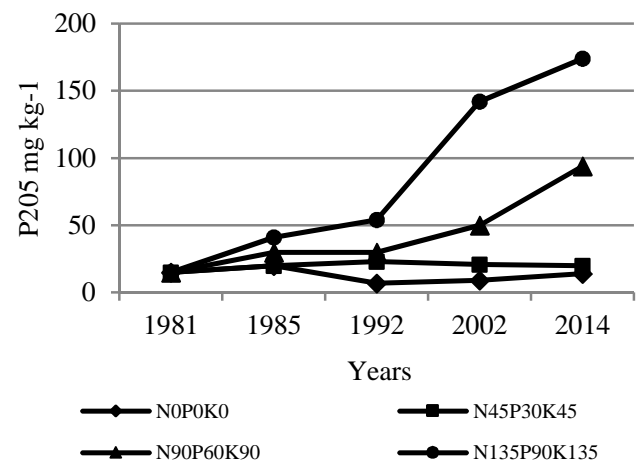

Fig.1. The changes of content of available phosphorus in soil without liming, 1981-2014

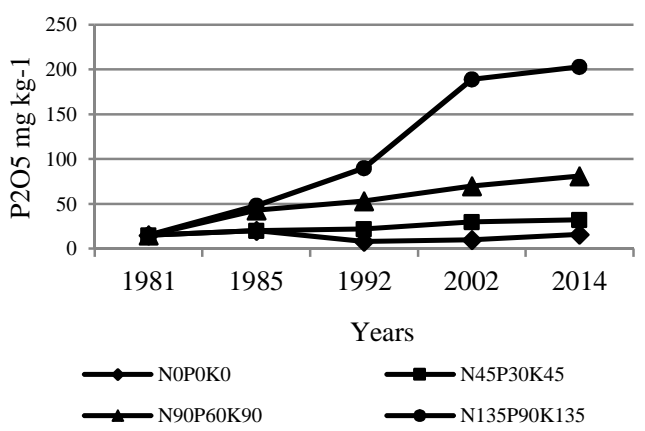

Fig. 2 The changes of content of available potassium with liming (11.40 $\left.\mathrm{t} \mathrm{ha}^{-1} \mathrm{CaCO}_{3}\right)$

In variant without fertilizers (L0) available potassium content did not change significantly during the experiment but the liming provided the increase of available phosphorus content in soil from 14 (L0) to $36 \mathrm{mg} \mathrm{kg}^{-1}$ (L3). In 2014 the content of available phosphorus characterized as very low.

At fertilizer rate $\mathrm{F} 1$, available $\mathrm{P}$ only started increasing 20 years after the establishment of experiment [18]. Liming provided the increase of available phosphorus content in soil from 20 (L0) to $41 \mathrm{mg} \mathrm{kg}^{-1}$ (L1). In 2014 the content of available phosphorus characterized as very low to low.

In variant with fertilizer rate $\mathrm{F} 2$, the available potassium increased slowly yet gradually [18]. The influence of liming on content of available phosphorus was significant. In 2014 the content of phosphorus in soil was 60 (L0) to 81 (L3) $\mathrm{mg} \mathrm{kg}^{-1}$. The level of available phosphorus corresponds to average.

In variant with fertilizer rate $\mathrm{F} 3$, the growth of available phosphorus was faster than in variants with lower fertilizers [18]. The influence of liming on content of available phosphorus was significant. In 2014 the content of phosphorus in soil varied from174 (L0) to 203 (L3) $\mathrm{mg} \mathrm{kg}^{-1}$ depending on liming rate. The level of available phosphorus corresponds to high to very high.

The results of research show that the liming provided the increase of available potassium in soil (Fig. 3 and Fig. 4).

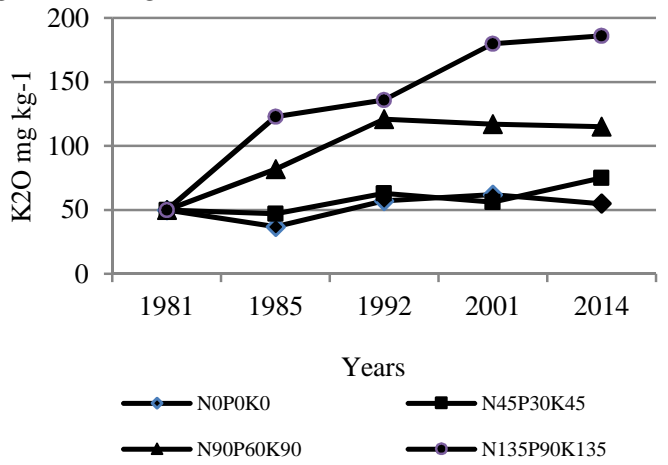

Fig. 3The changes of content of available potassium in soil without liming, 1981-2014

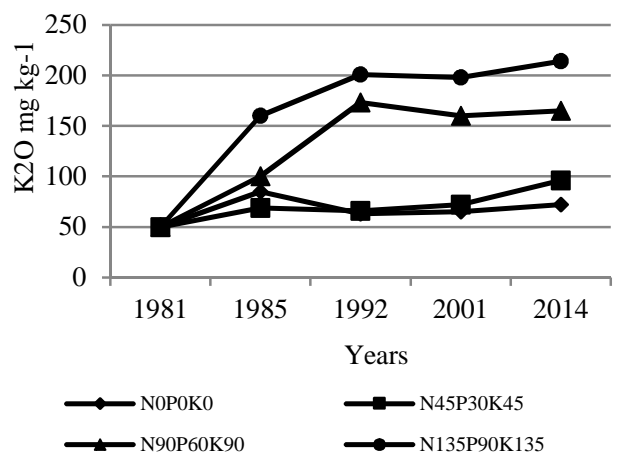

Fig. 4 The changes of content of available potassium in soil with liming (11.40 $\left.\mathrm{t} \mathrm{ha}^{-1} \mathrm{CaCO}_{3}\right)$

In variant without fertilizers (L0), the content of available potassium did not change significantly during the experiment [18] but the liming provided the increase of available potassium in soil from 55 (L0) to $72 \mathrm{mg} \mathrm{kg}^{-1}$ (L3). The content ofavailable 
potassium after 32 years in all plots of experiment characterized as low.

On a low background of fertilizers (F1) available potassium started increasing only in 2002 [18]. The content of potassium under liming increased respectively from 75 (L0) to 96 (L3) $\mathrm{mg} \mathrm{kg}^{-1}$ for potassium (in 2014). The content of available potassium characterized as low (L0, L1, L2) to medium (L3).

In variant with fertilizer rate $F 2$, the available potassium enhanced rapidly and in 1992 stabilized, but during the last ten years the content of $\mathrm{K}$ started decreasing [18]. The content of potassium increased respectively from 115 (L0) to 165 (L3) $\mathrm{mg} \mathrm{kg}^{-1}$ and in plots characterized as medium.

In variant with fertilizer rate $\mathrm{F} 3$, available potassium intensified very rapidly and reached a high level within five years. During the next period, the plant available potassium increased slightly but gradually [18]. The content of potassium increased from 186 (L0) to 214 (L3) $\mathrm{mg} \mathrm{kg}^{-1}$ for potassium and characterized as high.

On the basis of these results it can be stated that liming enhances soil agrochemical properties - mostly acidic reaction provided the increase of availableplant macronutrients like phosphorus and potassium in fertilized and non-fertilized plots over 30 years period.

\section{CONCLUSIONS}

The periodical liming provided the stable increase of available phosphorus and potassium in soil for long-term period.

The full and double of calculatedliming rate significantly influenced the availability of phosphorus and potassium in soil.

\section{ACKNOWLEDGMENTS}

This work was supported by the European Regional Development Fund within the project Development of Technology of Reduction of Environmental Pollution Using Mineral Fertilizers (No. 2010/0232/2DP/2.1.1.1.0/10/APIA/VIAA/097)

\section{REFERENCES}

[1] A. McCauley, C. Jones and J. Jacobsen, Soil pH and organic matter, Nutrient Management Module, No. 8, 2009, p. 12.

[2] G. Tyler, T. Olsson. „Concentrations of 60 elements in the soil solution as related to the soil acidity", European Journal of Soil Science, vol. 52, pp. 151-165, 2001

[3] I. Jaskulska, D. Jaskulski and M. Kobierski, „Effect of liming on the change of some agrochemical soil properties in a long-term fertilization experiment", Plant, Soil and Environment, vol. 60 (4), pp. 146 - 150, 2014.

[4] J. Alves dos Santos, A. Ferreira da Fonseca, D. Zocco and I. Vieira, "Exchangeable cations and available phosphorus in soils with variable charge after application of special liming materials", African journal of Agricultural research, vol. 11 (30), pp. 2744 - 2760, 2016.
[5] S. Fischer, H.-J. Koch and K. Bürcky K. "Effect of liming central European loess soils on soil extractable phosphorus and potassium as determined by electro-ultrafiltration", Archives of Agronomy and Soil Science, vol. 61, Issue 6, pp. 725 - 736, 2015.

[6] E. M. Muindi, J. P. Mrema, E. Semu, P. W. Mtakwa, C. K. Gachene and M. K. Njogu. "Lime-Aluminium- Phosphorus Interactions in Acid Soils of the Kenya Highlands", American Journal of Experimental Agriculture, vol. 9 (4), pp. 1-10, 2015.

[7] M. Szymańska, M. Korc and J. Łabętowicz, "Effects of single liming of sandy soils not limed for more than 40 years in the light of results of long-term fertilizing experiment", Polish Journal of Soil Science, vol. 4, pp. 105-114, 2008

[8] N. Özenç and D.B. Özenç, "Interaction between available phosphorus and lime treatments on extremely acid $\mathrm{pH}$ soils of hazelnut orchards", ISHS Acta Horticulturae, vol.. 845, pp. $379-386,2009$.

[9] M. Rastija, V. Kovacevici, D. Rastija, P. Ragaly and L. Andric, Liming impact on soil chemical properties, Agroecology and Organic Agriculture::45. hrvatskii 5. Međunarodni simpozija gronoma, Veljače 15-19, 2010, Opatija, Hrvatska., pp. 124 - 127.

[10] V. Antoniadis, F. Hatzis, D. Bachtsevanidis and S. D. Koutroubas "Phosphorus Availability in Low-P and Acidic Soils as Affected by Liming and P Addition", Communications in Soil Science and Plant Analysis, vol. 46, Issue 10, pp. 1288-1298, 2015.

[11] M. Jelic, J. Milivojevic, V. Djekic, O. Nikolic, N. Deletic and M. Biberdzic, The influence of liming and fertilization on yield and nitrogen and phosphorus use in winter triticale plants at pseudogley type soil: Proceedings of conference Research people and actual tasks on multidisciplinary sciences, June 24 - 28, 2015, Lozenec, Bulgaria, pp.78-82.

[12] V. Kovacevic, M. Rastija, D. Rastija and R. Sudar, Impacts of liming on grain yield, nutritional status and quality of wheat:, Proceedings of the 24th International ScientificExpert-Conference of Agriculture and Food Industry, September 25-28, Sarajevo, Bosnia and Herzegovina, 2013, pp. 331-335.

[13] H. Zhanga, J. L. Schroder, R. L. Davisc, J. J. Wangd, M. E. Paytonb, W. E. Thomasone, Y. Tangf and W. R. Rauna, "Phosphorus loss in runoff from long term continuous wheat fertility trials", Soil Science Society of America Journal, vol. 70, No. 1, pp. 163 - 171, 2005.

[14] I. Jokubauskaite, D. Karčauskiene, Š. Antanaitis, J. Mažvila, A. Šlepetiene, D. Končius, L. Pialaukaite-Motuziene, "The distribution of phosphorus forms and fractions in Retisolunder different soil liming management", Zemdirbyste-Agriculture, vol. 102, No. 3, pp. $251-256$, 2015.

[15] N. Athanasea, R. Vickya, M .N. Jayneb and H. Sylvestre, "Soil acidification and lime quality: sources of soil acidity, its effects on plant nutrients, efficiency of lime and liming requirements", Agricultural Advances, vol. 2(9), pp. 259 $269,2013$.

[16] R. Das and D. Saha, "Effect of liming on the changes of different forms of potassium in an acid soil treated with $\mathrm{N}$ and K fertilizers", Journal of the Indian chemical society, vol 91 (9), pp. 1619 - 1625, 2014.

[17] J. Vigovskis, A. Jermuss, A. Svarta and D. Sarkanbarde "The changes of soil acidity in long-term fertilizer eksperiments", Žemdirbystė = Agriculture, Vol.103 (2), pp. $129-134,2016$.

[18] J. Vigovskis, A. Jermuss, A. Svarta and Sarkanbarde, The changes of nutrient content in soil in long-term fertilizer experiments: Materials of the $10^{\text {th }}$ international Scientific and practical Conference: "Environment. Technology. Resources.”, June 18-20, 2015, Rezekne, Latvia, vol 2, pp. $329-332$. 